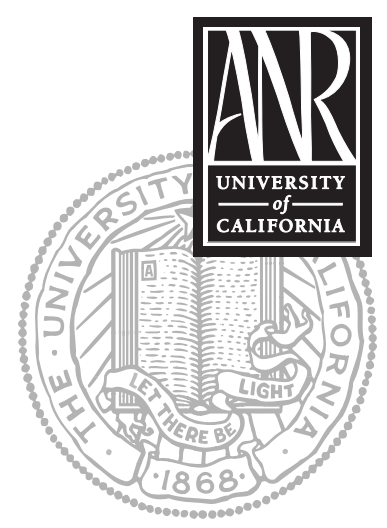

UNIVERSITY OF CALIFORNIA

Division of Agriculture and Natural Resources http://anrcatalog.ucdavis.edu

\title{
NUTRITION AND HEALTH INFO SHEET General Nutrition and Health Guidelines
}

ERIN DIGITALE, Department of Nutrition, University of California, Davis; CRISTY HATHAWAY, Research Assistant, Department of Nutrition, University of California, Davis; KARRIE HENEMAN, Assistant Project Scientist, Department of Nutrition, University of California, Davis; SHERI ZIDENBERG-CHERR, UC Cooperative Extension Nutrition Science Specialist, Department of Nutrition, University of California, Davis

The human body needs enough energy (calories) and nutrients to work properly and to maintain good health. In the last few years, health experts have concluded that the quality of life may be improved through healthy eating habits and regular exercise. Healthy eating is based on nutrient needs from a variety of foods over several days. Remember, moderation is the key.

The following recommendations for healthy living have been adapted from the 2005 Dietary Guidelines for Americans, ${ }^{1}$ directed at people aged 2 years and over. These guidelines recommend that most Americans eat less, exercise more, and make sensible food choices. ${ }^{1}$

\section{ADEQUATE NUTRIENTS WITHIN CALORIE NEEDS}

The 2005 Dietary Guidelines recommend that individuals take the following steps to ensure that nutrient needs are being met within an appropriate amount of calories:

- Choose nutrient-dense foods with little saturated and trans fats, cholesterol, added sugars, salt, and alcohol.

- Follow a balanced diet plan such as MyPyramid or the DASH (Dietary Approaches to Stop Hypertension) Eating Plan.

\section{WEIGHT MANAGEMENT}

Being too fat or too thin may lead to health problems. A "healthy" weight depends on how much of the body weight is fat and where the fat in the body is found. Family history plays a role in body size and shape. A physician or registered dietitian can help provide individuals with an ideal weight for height value. Individuals at a healthy weight are recommended to avoid weight gain. Those individuals who are already overweight should first aim to prevent further weight gain and then lose weight to improve health. Managing weight is easier if long-term changes in eating behavior and physical activity are adopted. For example, individuals can make the following changes to their lifestyle:

- Choose sensible portion sizes, and choose desserts wisely.

- Get moving. Get regular physical activity to balance calories from the foods eaten.

- Remember that although heredity and the environment are important influences, behaviors help determine body weight.

\section{PHYSICAL ACTIVITY}

Exercise is healthy for all age groups. It reduces the risk of developing heart disease, strengthens the heart and lungs, improves blood pressure, prevents diabetes in adults, keeps a person fit and helps manage weight. Current recommendations suggest par- 
ticipating in at least 30 minutes of "moderate intensity" exercise such as hiking, walking (3.5 mph) or easy gardening most days of the week. For most people, exercising longer or harder can increase health benefits. For weight management, 60 minutes of "moderate to vigorous" exercise such as walking (3.5 to $4.5 \mathrm{mph}$ ), aerobics, or running ( $5 \mathrm{mph}$ ) on most days of the week is recommended. Finally, for weight loss, 60 to 90 minutes of moderate-intensity physical activity on most days of the week is recommended.

\section{FOOD GROUPS TO ENCOURAGE}

Choose a variety of foods from all of the food groups, especially fruits and vegetables ( 2 cups fruit and $21 / 2$ cups vegetables), whole grains ( $3 \mathrm{oz}$ ), and milk products ( 3 cups). The forms and ratios of nutrients found in food vary within each food group. No single food can supply all the needed nutrients.

\section{Fats}

Diets high in fat may increase the risk of developing obesity and certain types of cancer, as well as increasing the risk for heart disease. The Dietary Guidelines recommend that total fat intake should be kept between 20 and 35 percent of total calories, less than 10 percent of total calories should come from saturated fat, and cholesterol consumption should be kept under $300 \mathrm{mg}$ per day. Furthermore, it is recommended that trans-fat intake be kept as low as possible. To reduce fat in the diet, follow these suggestions:

- Use the Nutrition Facts label to choose foods lower in fat, saturated fat, and cholesterol.

- Choose fat-free or low-fat dairy products, cooked dry beans and peas, fish, and lean meats and poultry.

- Limit the use of oil, shortening, and margarine when preparing foods (i.e., substitute fruit juices for part of the oil in salad dressings and for cooking).

- Limit the use of margarine, butter, cream, and salad dressing at the table.

- Trim fat from meat and remove skin from poultry.

- Boil, bake, roast, or broil meats and other foods instead of frying.

\section{Carbohydrates}

Vegetables, fruits, and whole grains are excellent sources of carbohydrates. These foods play an integral part in adding variety to the diet and are generally low in fat. Specifically, these products provide:

- some complex carbohydrates (which break down to produce the energy needed by the body)

- fiber (which helps prevent constipation and may also reduce the risk of developing intestinal cancers)

- many essential vitamins and minerals

Sugars, another source of carbohydrates, are found in many forms, such as table sugar (sucrose), brown sugar, fructose, honey, corn syrup, molasses, and fruit juice concentrate. Sugars and many sugary foods are high in calories and limited in nutrients. Take care not to let soft drinks or other sweets crowd out other foods needed to maintain health, such as low-fat milk or other good sources of calcium. Excess sugar consumption can contribute to tooth decay. Teeth should be flossed regularly and brushed with toothpaste containing fluoride. 


\section{Sodium and Potassium}

Sodium is in salt and many other foods. The 2005 Dietary Guidelines recommend limiting salt consumption to 2,300 $\mathrm{mg}$ per day, as too much can contribute to high blood pressure. Listed below are ways to reduce the use of salt and sodium:

- Limit the consumption of salted snacks, such as chips, crackers, pretzels, and nuts.

- Check the labels for the amount of sodium in foods. Choose those lower in sodium most of the time.

- Flavor foods with herbs, garlic, pepper, and other spices.

- Use salt sparingly, if at all, in cooking and at the table.

\section{Consider the following facts when making food choices:}

- Fresh and plain frozen vegetables are lower in sodium than canned vegetables.

- Fresh fruits and vegetables are high in potassium, a nutrient which reduces the effects of salt on blood pressure, making them an excellent food choice.

- Milk and yogurt are lower in salt than cheese.

- Fresh meat, poultry, and fish are lower in sodium than most canned and processed ones.

\section{Alcoholic Beverages}

Alcoholic beverages supply little or no nutrients. If adults choose to drink alcoholic beverages, they should do so in moderation. Moderation is considered 1 drink (for example, a glass of wine) per day for women and 2 drinks per day for men. The following people should not drink alcoholic beverages:

- children and adolescents

- women who are pregnant or trying to get pregnant (as alcohol may cause major birth defects)

- individuals who plan to drive or engage in other activities that require attention or skill

- individuals using medicines, including over-the-counter kinds

- individuals who are alcoholics

\section{FOOD SAFETY}

Foods that are safe from harmful bacteria, viruses, parasites, and chemical contaminants are vital for healthful eating. Safe means that the food poses little risk of foodborne illness. Farmers, food producers, markets, food service establishments, and other food preparers have a role in keeping food as safe as possible. However, foods should also be stored and prepared safely in the home, and individuals should be alert when eating out. 
Follow the rules below to keep your food safe:

- Clean. Wash hands and surfaces often.

- Separate. Separate raw, cooked, and ready-to-eat foods while shopping, preparing, or storing.

- Cook. Cook foods to a safe temperature.

- Chill. Refrigerate perishable foods promptly.

- Avoid. Avoid raw (unpasteurized) products such as milk, eggs, meat, juices, or sprouts.

Be very careful with perishable foods such as eggs, meats, poultry, fish, shellfish, milk products, and fresh fruits and vegetables. Those individuals at high risk of foodborne illness, including pregnant women, young children, elderly persons, and people with weakened immune systems or certain chronic illnesses, must be extra careful.

\section{REFERENCES}

1. U.S. Department of Health and Human Services and U.S. Department of Agriculture. 2005. Dietary guidelines for Americans, 2005. 6th Ed. Washington, DC: U.S. Government Printing Office. Dietary Guidelines for Americans Web site, http://www.health.gov/dietaryguidelines/dga2005/ document/pdf/DGA2005.pdf.

2. Food and Nutrition Board, Institute of Medicine. 2002. Dietary reference intakes for energy, carbohydrate, fiber, fat, fatty acids, cholesterol, protein, and amino acids (macronutrients). Washington, DC: National Academy Press.

\section{FOR FURTHER INFORMATION}

To order or obtain ANR publications and other products, visit the ANR Communication Services online catalog at http://anrcatalog.ucdavis.edu. You can also place orders by mail, phone, or FAX, or request a printed catalog of our products from

University of California

Agriculture and Natural Resources

Communication Services

6701 San Pablo Avenue, 2nd Floor

Oakland, California 94608-1239

Telephone 1-800-994-8849

(510) 642-2431

FAX (510) 643-5470

E-mail: danrcs@ucdavis.edu

An electronic version of this publication is available on the ANR Communication Services Web site at http://anrcatalog.ucdavis.edu.

This publication has been anonymously peer reviewed for technical accuracy by University of California scientists and other qualified professionals. This review process was managed by the ANR Associate Editor for Food and Nutrition.

Publication 8140

ISBN-13: 978-1-60107-497-3

(C) 2008 The Regents of the University of California

Division of Agriculture and Natural Resources

All rights reserved. 
No part of this publication may be reproduced, stored in a retrieval system, or transmitted, in any form or by any means, electronic, mechanical, photocopying, recording, or otherwise, without the written permission of the publisher and the authors.

The University of California prohibits discrimination or harassment of any person on the basis of race, color, national origin, religion, sex, gender identity, pregnancy (including childbirth, and medical conditions related to pregnancy or childbirth), physical or mental disability, medical condition (cancer-related or genetic characteristics), ancestry, marital status, age, sexual orientation, citizenship, or status as a covered veteran (covered veterans are special disabled veterans, recently separated veterans, Vietnam era veterans, or any other veterans who served on active duty during a war or in a campaign or expedition for which a campaign badge has been authorized) in any of its programs or activities. University policy is intended to be consistent with the provisions of applicable State and Federal laws.

Inquiries regarding the University's nondiscrimination policies may be directed to the Affirmative Action/Staff Personnel Services Director, University of California, Agriculture and Natural Resources, 1111 Franklin Street, $6^{\text {th }}$ Floor, Oakland, CA 94607-5201, (510) 987-0096. For information about ordering this publication, telephone 1-800-994-8849.

pr-1/08-LR/CM 